Article

\title{
Turning Points in the Lives of Chinese and Indian Women Leaders Working toward Social Justice
}

\author{
Rosanna Hertz
}

Departments of Sociology and Women's and Gender Studies, Wellesley College, Wellesley, MA 02481, USA; rhertz@wellesley.edu; Tel.: +1-781-283-2538

Academic Editor: Nancy A. Naples

Received: 20 June 2016; Accepted: 8 October 2016; Published: 13 October 2016

\begin{abstract}
Institutional change has a human face. This paper explores how a select group of women in China and India experienced economic and political turmoil and why they chose to become change agents. Through in-depth interviews with 40 women from NGOs, government agencies and private business, four broad moments in the evolution of a change agent are identified and discussed: (1) awareness of a double-bind; (2) reframing the tension induced by that double-bind; (3) becoming an agent of change; and (4) building a vibrant network. To highlight these key features, four women's narratives are discussed in greater depth from recognizing injustice to taking a non-traditional stand. The paper concludes with a call for further comparative work on the role of personal narratives in shaping a movement for change.
\end{abstract}

Keywords: Chinese women; India women; leadership; defining moments; activism

\section{Introduction}

The growth of markets, formalized employment practices and more pronounced income stratification have accompanied development in India and China over the past two decades [1,2]. Institutions like family, community and religion have been strained in the process, presumably leading to the emergence of more change agents to lead movements for and against economic change. What is not clear, however, is why some people move from observers to actors and whether their journeys run in parallel or diverge.

This paper explores how 40 women from China and India were transformed-and transformed themselves-from objects of change into agents for change during an era of intense economic change. The goal is to deepen our understanding of how the intersection of individual experience and structural shifts lead some women to oppose, promote or redirect change. Thus I ask: what did these women do with the experience of structural shifts that made them into change agents?

The women are individual and unique, of course, but their stories trace a trajectory that is remarkably similar. Motivating each story is a profound tension between opposing forces: a dialectic resolved by expanding the field of play from personal to public, by finding viable alternatives to inaction, and by building networks to share resources. At the heart of every story is a crucible. That is, a time of testing and profound discomfort from which an individual emerges with a new sense of self and a host of tools and strategies for leading others. ${ }^{1}$

In the sections that follow, I set the context for this study of change agents by situating the group of 40 women I interviewed in time and place and explaining why I chose them for study. I then describe the conceptual frame I employed to organize insights from the interviews about change-agents-a

1 Robert J. Thomas ([3], p. 18) argues that crucibles vary enormously but they change the status quo for the individual who experience that translates into greater investment in organizations, communities and activism. 
frame developed by Thomas [3] and by Bennis and Thomas [4] in their research on crucible stories from accomplished leaders. Though the trajectory for becoming a change agent is derived from 40 interviews, I highlight the different moments in the trajectory by means of detailed stories from a subset of four women. These women represent the trajectory experienced by the overall sample. They were also chosen strategically to reflect the range of different forms of engagement with their respective governments.

\section{Studying Change Agents in Context}

India and China provide a value backdrop for the study of change agents. In both countries, women are still expected to abide by tradition. Development may have expanded labor market opportunities but women continue to do invisible work in the joint household and occupy sideline positions even in civil society $[1,5,6]$. Differences in state structure make it possible to explore routes to becoming a change agent, too. In China, the state has played a direct (commanding) role in economic development. Its authoritarian, one-party system of governance has systematically thwarted opposition to its policies or their consequences [1]. Becoming a change agent in China was not likely to have been a simple choice. On the other hand, India's fractious parliamentary democracy-built on tenuous coalitions representing ethnic, religious, economic and ideological interest groups-may have provided more fertile ground for the emergence of change agents; but it also created more intense competition for influence and resources [7].

Selection of India and China also gives us a useful window on the role of feminist ideology in the process of becoming a change agent. In particular, it allows us to test the proposition put forward by Ferree and Tripp ([8], p. 6) that " ... many mobilizations of women start out with a non-gender-directed goal, such as peace, antiracism, or social justice, and only later develop an interest in changing gender relations." In other words, do feminist views precede, accompany or follow structural shifts in the economy?

\subsection{Sample and Methods}

In order to learn more about how women became change agents, I interviewed 40 women from India and China who were between the ages of 40 and 75 in 2010 and 2011. Many of the women had been teenagers or were in their twenties during the peak of economic development. Often they were among the first women to enter a line of work or to find niches that were newly opened to them. I updated all of their interviews in 2012 through telephone and video conversations to capture any new developments in their lives. I also used these conversations to clarify their biographical trajectories. ${ }^{2}$

I relied on key informants to create a pool of women who were part of the social transformations occurring in India and China. Interview candidates were referred to me because they were regarded as leaders in their respected fields. ${ }^{3}$ Independent of their current role, I sought out women who for a prominent part of their careers had been change agents working "within the system." The goal, as I explained it in an email introducing the project, was to understand how they might "stretch everyone's thinking about what is possible." Once I had a list of interview candidates, I used the Internet to fill in details on the women's present positions. This made it possible for me to draw from a variety of work sectors in the major geographic areas I had selected as research sites.

2 In every research study, I leave open future contact so that I can to clarify ambiguities or add in essential missing information. It is hard to juggle listening, note-taking and asking questions at the same time [9].

3 To identify others in each country, I drew from a list of Wellesley College alums who were native to India and China. The alumni network is influential, well-connected and willing to help generate names. I note that I deliberately only interviewed one Wellesley alum in India and one in China because I did not want to skew the sample to those who had received Wellesley or U.S. undergraduate degrees. Only these two women received their B.A. degrees outside of their respective countries. 
To locate Indian respondents, I began by asking U.S. colleagues who conduct research or have lived in India for help identifying noted women in the fields of business, NGOs and government. My institution has several programs in India for undergraduates. I also wrote to a colleague at the University of Mumbai who also made recommendations and looked over the list I had from my U.S. colleagues. Colleagues wrote email notes of introduction to eight women and they agreed to be interviewed. However, I received no responses from women on the list whom I approached without a personal introduction. Once I realized that I needed someone who could vouch for the project, I turned to a well-known business person and political figure, who is a family friend. I gave him the list I had generated and I also asked if he had additional suggestions. Since many of these women were nationally recognized as innovators in their respective fields, I asked for his help in gaining access. This time these women responded. I realized that I could only gain access through the strength of weak ties [10]. In India I interviewed women who lived in metropolitan Mumbai, Delhi and Hyderabad.

To locate Chinese respondents, I wrote to two key women from Beijing whom I had met at conferences sponsored by the Ford Foundation and the Wilson Foundation. I asked these women to write on my behalf to women I had identified as potential interviewees. Having worked on the India list first I learned that I needed their sponsorship to gain access. I also had my research assistant translate a note from me into Mandarin. In China, I interviewed women mainly in Beijing.

The current positions of the women in both countries did not always correspond to private/public sector distinctions made in the U.S. At the time of the interview the women were situated in variety of fields in business, law, social media, government (elected officials or state owned public sector institutions) or international organizations (e.g., World Health Organization). Depending on the country NGOs could be either "civil organizations" (e.g., non-government and non-business organizations) or ones that received official approval by the government. ${ }^{4}$ In China, several women had started NGOs (e.g., hotlines, and social services) that were government authorized; others did not have official government sponsorship because their projects conflicted with the prevailing government agenda. Several of the women were appointed by their respective governments to become members of high-level committees or commissions.

These were, for the most part, educated but not elite women in terms of their backgrounds. All had received B.A. degrees in their home countries, with the exception of two women who earned B.A. degrees in the U.S. Sixty percent held advanced degrees. All of the Indian women were married but only $60 \%$ of the Chinese women were married. All of the married women had children. Unmarried Chinese women did not have children. One woman from China identified as lesbian and she had a partner. The majority $(80 \%)$ had spent some time in foreign countries such as Britain, Australia, the U.S. or Japan often through Fellowship Programs (Ford, Fulbright, and cultural exchanges through other host countries) or had received an advanced degree or a shorter certificate outside of India or China. Indian women in business often had relocated for a period of time to Britain, the U.S. or Singapore.

Among the five oldest Chinese women, aged 60 or older, all had attended the 4th World conference on Women held in Beijing. Younger women mentioned the conference as important to framing social justice even though the conference was not listed as a personal turning point. The U.N. Conference inspired women to create economic and socially just societies and encouraged women's participation in globalization. It drew upon a human rights framework that transcended individual countries and offered them feminist networks and resources [13]. Women's organizing for reform in China has always been complex. Paradoxically, Judd ([14], p. 2) argues that the State's official women's movement, the Women's Federations in the 1980s, helped precipitate a set of politics that lead rural women to

Civil society organizations are critical in the advancement of human rights, the environment, labor practices, etc. In China, the government does not recognize all active NGOs and most of them are not registered, which is a marker that this "sector" is problematic [11]. China has placed further restrictions on foreign organizations and their local partners who are required to have official Chinese sponsorship and to be registered with the police (e.g., environmental, philanthropic and cultural exchanges) [12]. 
become part of the "socialist market economy." Overall, women's rights remained subordinated to the patriarchal vision of the Community Party. Outcomes for China's older women in this study from the Beijing conference included groups which formed around key issues such as domestic violence, trafficking, job discrimination, land inheritance rights and family laws. Younger women acquired a language of human rights and social justice through their "elders." Student-led demonstrations in Tiananmen Square in 1989 became a pivotal event for the younger Chinese women in this research project. In India, contemporary women's movement protests began in the 1970s, though today the women's movement is decentralized with hundreds of smaller groups on a vast range of issues [15].

I asked each woman to complete a timeline identifying the "turning points" that, to her mind, best explained how and why she became a change agent. The timeline was divided into five-year intervals. The timelines became a focal point of the interview: a way to understand the connections between the particular social environments of individuals and the wider biographical and historical forces in which they were enmeshed [16]. Regardless of the women's age at the time of the interview, the women circled approximately the same ages on their timeline reflecting personal milestones such as high school graduation, selection as head girl, winning sports or special recitals, entry into college, first jobs, going abroad. ${ }^{5}$ A second set of timeline circles varied by age. These moments were embedded in the local social environments individual women experienced, such as historical events, encounters with government policies or women's shift in job location (i.e., from the private sector to the public sector).

I audio-recorded the interviews. Interviews averaged $1.5 \mathrm{~h}$ in length and took place mostly in offices where the women worked. If there was no quiet place to talk, I offered my hotel as an option. In China, I hired a research assistant to translate when necessary. However, only two women needed a full translation and one of these women understood English but preferred to speak in Chinese. All of the other China women preferred to speak in English occasionally asking my research assistant to translate a phrase that was not clear between us. Women also gave me websites or documents that needed translation. In India, the interviews were conducted in English. I transcribed the interviews. My research assistant and I coded the interviews two ways: one for ages circled and the other using 13 analytical codes I developed out of the timeline events (such as experiences of injustice, learning to lead, etc.). I am using pseudonyms to protect confidentiality even though all the women gave me signed consent to use their real names. I do so because this is a way to ensure that government and/or opposition groups cannot hold them accountable.

\subsection{Four Women's Stories}

In framing this article, I use a vignette format to give the reader greater visibility into the process of becoming a change agent. The specific women were chosen to reflect differences in cultural and work contexts. I chose two women from each country. I selected four activists in NGOs or public sector organizations because the vast majority of the women I interviewed (80\%) worked in that domain. ${ }^{6}$ I deliberately selected to focus on two women from each country for this article in order to contrast the circumstances and capture the dilemmas they faced as they became change-agents. Two women were chosen because they worked in NGOs and the other two because they worked in the public sector. These four women reflect the diversity of the interviewees.

Finally, my intent was not to study transnational feminists but to ask about the key moments of local struggles that might have been influenced by transnational politics and feminism or that led to involvement in either. In other words, I was interested in women who became change-agents and how

5 Relevant personal milestones are discussed in the narratives. Women also listed marriage and children as turning points. Work/family issues are beyond the scope of this article.

6 The remaining eight women work in businesses of various sorts (e.g., family owned, business social entrepreneurs or multi-national corporations). Their experiences can be portrayed using the same overarching conceptual framework though their engagement with their respective governments is often buffered by other regulatory systems beyond this paper. 
they related their life's work to social justice causes. The model I present in organizing the findings captures the experiences of all the women in this research project.

For clarity sake, it helps to briefly introduce each woman.

Lijuan Zhao is one of China's leading public interest lawyers. We met on her day off in a small tearoom and then moved to my nearby hotel room so we could audio-tape the interview in quieter conditions. Lijuan, age 40, was born in southwest China. An outspoken environmental advocate, she represents pollution victims in law suits and promotes public participation by helping communities organize public hearings on environmental rights and licensing processes. Hers is a difficult area of law because the state often puts economic development ahead of environmental issues. Not surprisingly, she frequently encounters government opposition. Despite her efforts, Lijuan has only won one case. However, this victory is legendary among farmers. She continues to spend her time helping rural farmers cope with pollution from China's expanding mega-cities.

Wei Wang is from Beijing and, at age 42, is director of an LGBT organization not officially registered with the government because of its political agenda. We met in her office located in an apartment building indistinguishable from dozens of others on the outskirts of the capital. In 2008, her organization and a few others formed a local network that does community organizing around social justice for LGBT individuals. Their focus is on youth outreach and alliance building. Even though the government no longer considers homosexual identity a punishable offense, Wei knows that some things will catch the government's attention, like summer camps for lesbian youth. These are offered but they are not advertised in a public arena such as on their Internet page. She knew that she was being monitored: "For us it's hard to say how much the government cares ... the police recently shut down a rally ... [but] we continue to exist." Still, she and her network reach out to a marginalized LGBT community, regardless of geographic locale, with ingenious tactics, e.g., utilizing technology to send weekly text messaging that appear as advertisements to boost the morale of LGBT individuals. Social media is now a common strategy used by activists throughout the world $[1,8]$. Wei hopes that the government will have a more open policy toward NGOs, similar to other countries, so that the "whole civil society will have the space to develop."

Leena Patel and I met at her office in Mumbai before the heat of the day. As we got acquainted, Leena, now 61, described herself as a pebble skimming the ocean waves and skipping from one accomplishment to another. Her focus at the time of our interview was the Humanity Foundation, a well-known NGO dedicated to the elderly in India. Aging is classless, she told me, and with the decline of the joint family she worried that the aging would suffer in years ahead. In her early 40s she started a magazine that proved to be an effective platform for reaching the literate elderly. Later, her organization began offering social services, including "project companionship" where social counselors offer services to lonely seniors whose children often live abroad. In 2009, the Indian government appointed her to a commission to review the aging problem. That post enabled Leena to partner with organizations in the U.S. in order to learn about aging in the U.S. context. This gave her a place on the global map and helped her advance creating a network of residential facilities and outreach programs in every state in India.

Sanjukta Sinha and I met first on the phone and then several times in person, a product of her extensive travel schedule. She held many firsts in India in her career: the first woman Chairman and Managing Director of a public sector bank; first woman and first commercial banker to head a rural development bank; and the first woman commissioner of an anti-corruption board as part of the Government of India. Sanjukta, who was 64 years old at the time I interviewed, is best known for turning around a major Indian bank after years of stagnation and corruption. She was brought in by the government to fix the Indian Bank but refused to follow others' strong advice to "clean house" by firing middle management and bringing in troops of consultants. She eventually saved the jobs of 26,000 people-something she holds as one of her proudest accomplishments at the bank. As a result of her posting by the bank to a rural area, she realized that girls and women were disadvantaged 
because basic healthcare needs had not been meet. For rural development to advance she became an advocate for social issues that advanced children's and women's rights through her banking authority.

\section{Becoming a Change Agent}

As the stories of four women will demonstrate, the personal experience of social injustice led them to become change agents. Social injustice includes gender inequality but gender featured in a minority of crucibles stories. For example (as I will note in an upcoming section), the turning point in Lijuan's path to becoming a change agent occurred as a child when she tried to reconcile her dedication to learning and her experience of being denied access to university. Later as a change agent, she worked to empower farmers to petition the government for better regulations against corporate polluters. Mobilization in her mind was about achieving a more equitable distribution of power and wealth. ${ }^{7}$ In her case, as in many others, gender difference may have been embedded in the problem but it was not always its most visible feature, e.g., lack of sanitation in rural villages may have affected women differently than men but her focus was on the implications for children, irrespective of gender. Gender similarities, among the disadvantaged were not coincidental but when asked about the early experiences that shaped their focus on change the stories they told did not necessarily feature gender inequality.

Summarizing the experiences of forty women is not easy, but detailed analysis of the lengthy interview transcripts revealed that a common trajectory, composed of critical moments, connected them despite great differences in time and space. For example, recent works by Thomas [3] and Forenza and Germak [17] characterize the link between activism and empowerment as a developmental process. Bennis and Thomas [4] make the case that "crucible" moments can unfold over hours, days or even years and they may not result in an immediate epiphany or "aha." However, in retrospect, they take on meaning as a time or an event that catalyzed a long-term change. To paraphrase Aldous Huxley [18], experience matters, but what matters more is what people make of experience.

The timeline exercise and ensuing interview helped me utilize the concept of moments in a trajectory to capture something quite similar in the Indian and Chinese women I interviewed. Four broad moments emerged from the interview data: (1) awareness of a double-bind; (2) reframing the tension induced by that double-bind; (3) becoming an agent of change; and (4) building a vibrant network.

\subsection{Awareness of a Double-Bind}

Each woman I interviewed rooted her awakening to the need for social and economic change in the experience of a profound but very personal double-bind. I use the term double-bind intentionally. Virtually every time I asked a woman about the origins of her current work, whether it be about poverty or pollution or discrimination, I was told of an experience of inequality that had two sides: a profound negative reaction to unfairness and a powerful, sometimes sickening, realization that the status quo was deeply entrenched and not easily moved.

Lijuan Zhao, the environmental lawyer and activist, grew up with tales of her grandparents' hardscrabble existence in the countryside. She was reminded each day of how the sun scorched the rice fields as they worked long hours with children in tow. Those indelible memories served as a warning that, despite her parents' accomplishments (her mother had become a doctor and her father an engineer), Lijuan could be forced to return to the rice fields if she did not qualify to attend university.

Top scores on her university entrance exams seemed like insurance against such a fate, but at the time of application she was told that she did not meet the medical standards for admission. Since birth, her heart had made an unusual sound that doctors picked up with a stethoscope; she was otherwise

7 Indeed, gender solidarity proved useful in several instances as a vehicle for mobilizing resources, e.g., existing women's organizations were easiest to recruit in support of an effort. 
very healthy and no one made an issue of it. To her dismay, she was informed that her condition rendered her ineligible for university admission. As a result, her exam scores were not sent to any of the universities to which she applied. Lijuan burned with disappointment. A doctor's judgment had undermined everything she had assumed was possible for her in life:

“For many years I never mentioned this story because I think it's too personal ... most people cannot understand how important it is to be a university student because at that time it's the only opportunity for most young people. Either you go to university or you become workers and farmers."

Her experience was one of being ensnared in a double-bind: she had no independent evidence to counter the doctor's diagnosis yet if she accepted the medical judgment her life would be profoundly altered. ${ }^{8}$ Her prior academic accomplishments were negated in an instant by a government policy that offered no recourse. Though she eventually found her way into an experimental university, Lijuan recalled that crucible as even more powerful than Tiananmen Square. Despite the turmoil of that time, when loudspeakers threatened students first with forfeiture of their university places and then with violence, Lijuan said that it was her medical experience that alerted her to injustice that was both personal and structural in nature. Lijuan was not alone in the experience of a double-bind. More than just an inconvenience or the thwarting of a childhood dream, her experience and those of women like Leena Patel sparked a deep rejection of the status quo.

Leena Patel, who first worked in public health on the safety of street food and then later founded an NGO dedicated to care for the aging, grew up in Madurai in southern India and described how as a child she was torn between a caste system portrayed as natural and a personal sense of injustice about the way her family treated people of lower castes:

"They say that a child's sense of justice is near perfection. These were servants-which in itself is a demeaning term-who were looking after me, they were helping me, they were playing with me. But to see the elders in my family treat them badly was the first rude shock to my psyche. Then there was the ill treatment meted out to my dogs, pets by both my family and the domestics. I kept watching this cruelty of the higher caste toward animals and lower caste people and it didn't get my approval."

Leena could not fathom why caregivers who were central to her daily life at certain times in the day, were at other times in the day treated as second class citizens.

Awareness of a double-bind represents a moment in the process of transformation. It was not always immediate. It did not always arrive wrapped in an epiphany. However, when this moment occurred for each woman, she faced a situation in which she would be criticized for violating expectations but profoundly disappointed in herself if she accepted the cards she had been dealt.

\subsection{Reframing the Tension of the Double-Bind: Challenging Structural Injustice}

Important clues as to why these women continued on to a life of activism can be found in the fact that each woman reframed her double-bind so that there was a viable alternative to acquiescence. To use Hirschman's [19] formulation, beyond loyalty there was the possibility of either exit or voice. The women I interviewed chose voice. Two elements proved critical to the process of reframing. One element involved the realization than an individual injustice could have structural roots. The other element was the discovery that others had been successful in organizing against injustice. Wei Wang's story is a powerful example.

Wei Wang, director of an LGBT organization, dreamed of becoming an electrical engineer in part because politics made her uncomfortable. She was not adept at debating right and wrong the way her

8 There was ample evidence to suggest that this was not just the overstatement of disappointed teenager. 
sister did. However, she found herself in the grip of a double-bind when, after securing her degree, she began to seriously rethink her own sexual identity. Deeply aware that heterosexual marriage and family remained "very closed in the Chinese patriarchal value system," she nonetheless refused to lead a secret life. Wei preferred to be non-political but could not imagine living a life that was untrue.

In the mid-1990s, China only allowed certain institutions, such as Peking University, to have Internet access, as a way for China to control access to information and knowledge [1]. The Internet provided a safe space for her to explore new possibilities. Wei found, in her words, "a new world": "I was trying to get some LGBT related information and I found this news group and I sent in a message and people from different parts of the world replied. It was very crucial for me to get connected to other "alive" LGBT people. To be able to exchange experiences and to find out our similarities." This exposure over the Internet gave her a thirst to experience political movements up close.

She applied for a visa to study chemistry in the U.S. as an extension of her undergraduate major but also as part of a plan to experience being openly lesbian. Gay pride parades in New York City made an indelible impression on her: "This was the year that I and some friends actually set up an informal support network for lesbian and bisexual women from inner China, while we were in the States." With a laugh, she added: "It was kind of exciting for me. For the first time I thought, "To be in the movement is even more exciting than to watch it."'

She faced another double-bind. She could try to work for social justice from another continent or return to China where she knew the government could censor an LGBT organization. With encouragement from activists she knew in other countries, she decided to re-enter China and live with the risk of censorship. She thought about the government's repression of thought this way: "You have to be very sensitive politically speaking. As you go along, you make mistakes. You never completely know what will be a mistake. You never completely know what will become a mistake." (Emphasis by interviewee $)^{9}$ She felt she could be more effective returning home despite knowing that she would be living with inveterate uncertainties. Through the experience she gained in the U.S. and encouragement from colleagues abroad, she co-founded the Institute for Cultural Studies, which brought LGBT activists and scholars from Mainland China, Taiwan and Hong Kong together to help promote the visibility of the LGBT movement in Chinese speaking communities. She returned to China dedicated to working with other NGOs outside of the government in order to enact change.

Sanjukta Sinha, the first woman to chair and be managing director of an Indian public sector bank, dove into her career as a change agent in an institution noteworthy for its veneration of tradition, particularly the tradition of respect for rank and patriarchy. Her double-bind was multilayered. At the age of 19, she was thrilled to receive a letter from the State Bank of India inviting her to a job interview on completion of her university education. The offer was a clear affirmation of her accomplishments as a student even though she knew that the position she was offered would likely be a dead-end for a woman. The offer was extended in 1965 and Sanjukta was compelled by tradition and feelings of safety to travel only with an escort from her home in Hyderabad to Mumbai for the interview. Since her father and brother were unable to accompany her, she realized that she either had to refuse the opportunity or go against her parents' wishes and travel on her own. A railway employee whose job was to oversee the waiting area and offers travel information reinforced the magnitude of her dilemma from the moment she entered the train station:

"There was a woman who used to work like a caretaker in the train station and she asked me, 'Is there somebody with you?' I said, 'No, I'm by myself.' And she said, 'You know Mumbai is not the place for young girls to be by themselves. Be careful.' I was so scared."

9 The looming threat of government punishment in the form of enforced disappearances and "black jails" are tactics used to silence perceived dissents [20]. The government recently shut down a 20-year-old leading Women's Aid Center that arose from the United Nations Fourth World Congress. No reason for the shut down was provided. The closure signifies the tightened restrictions on civil society. A woman interviewed for this news report added "... controls on thought and speech are intensifying." [21]. 
Sanjukta persevered, in her words, because "the job interview came to symbolize the promise of an independent India-for me as a woman and for India as a nation trying to grow its own unique institutions." She reframed her travel to Mumbai as a personal victory against a seemingly inerasable restriction on women's freedom of movement [22]. ${ }^{10}$

Even as they discovered the structural roots of their personal experiences and observed that it was possible to address injustice even in small ways, these women recognized that making change in societies long-accustomed to severe inequality would demand more than just individual passion and persistence. Change would require insight and, ultimately, networks of resources.

\subsection{Becoming an Agent of Change: "First-Rate Noticers"}

Becoming a change agent required of these women insight into the leverage points for action. Insight came from awareness and empathy, skills characteristic what Bennis and Thomas [4] refer to as "first-rate noticers." They see things, like patterns of behavior and openings for action that others overlook. Like people who reside on the margins of formal organization, they notice connections that reveal the inner workings of the status quo. Acute observational skill, when combined with a deep sense of empathy, provides the kindling; it is a sense of right and wrong that sparks a move from simply seeing to decisively acting.

Leena, who earlier pointed her childhood observations about the treatment of servants, recalled how as the "head girl" (or most accomplished student) in her class she learned from her teachers how to manage people without raising her voice. She learned not to throw her weight around but to listen and learn instead. As much as she might have been from the upper caste she identified with those at the margins.

After receiving her M.A. degree in social work, Leena worked on street food safety in the slums as a social worker. There was no water, poor hygiene and the food was very often contaminated. She first thought the solution was to shut down the vendors. However, her observations in the field led to a change of heart:

"I realized that a poor man has a variety of food ... the most common street food is chow mein. Each vendor feeds 65 people in a couple of hours. Huge job opportunities. But it is not just the food-it is the conversation and the social interaction while you are eating that is important. While they eat at the tables they see an open sky, it is not just the food but the mental freedom, especially in the slums where 10 people sleep in a small room. I found this really positive. I decided right then that I had to do something about the quality of food ... This was my solution after looking around."

The lessons she learned about sensitivity to local practices and customs influenced her later in life when her work in public health took her to other countries in Asia and Africa. Her informal motto is to first observe the culture and then decide if, when and how to act.

Later in life, she set up her own organization for helping people who lacked a joint family household to support them in old age. The class and caste distinctions of her childhood come back to her, as she noticed the loneliness of old people. She realized that the joint family system was crumbling in urban areas as children migrated to other countries for better jobs, leaving their parents behind with no one to care for them. She created several initiatives and partnered with other women's activist organizations engaged in carework activities and sexual violence hotlines. She used her earlier successes to get the regional government to take notice. Armed with data she had collected about the lack of pensions and the need for adult caregivers, she convinced the government to set up a

10 Women do not need safety in public spaces but to counter fear with the "right to take risks" and enough women willing to do so [23-25]. Phadke and coworkers' [22] more recent data continue to illustrate that women still do not have equal claim to urban public spaces. Their access has only marginally improved since Sanjukta walked the same Mumbai streets. 
commission to make recommendations. They asked her to be a member (this commission had not finished its report at the time of her interview).

Like other first-rate noticers, Leena embodied a theme critical to becoming change-agents. Just as the slave knows the master inside out, those at the margins watch those who are central. First-rate noticers gather information that is usually overlooked-even by those in positions that benefit from inequality —and they act on it.

Lijuan began her career in corporate law despite her sojourn through an experimental university and her long-standing consciousness of environmental issues. However, her desire for social accomplishment, which was symbolized in a cushy corporate job, could not erase her youthful outrage at the arbitrariness of the government that sacrificed individual rights as the price of economic development. She recalled not only her university rejection but also the fact that her father had been assigned to a job in a chemical factory that was polluting the water near her family's home.

Eventually the contradiction between her values and her work precipitated a shift into work as an environmental legal aid attorney. She observed that ordinary people did not understand they had legal rights. Watching how the government ignored plants that were polluting rivers and fields she wanted disenfranchised farmers to know they had recourse. She kept returning to the villages to gain the cultural competency that would help her understand farmers' fear of working together.

Through their acute observation and deep sense of empathy, women like Leena Patel and Lijuan Zhao not only found ways to solve problems that others had overlooked but they also empowered those without a voice.

\subsection{Building Vibrant Networks}

Changes may start with an individual's crucible, but sustained change takes resources. ${ }^{11}$ At different points in their careers, these women reached a similar conclusion: it would be easier to enact change as part of a group. By connecting with others and forming social networks, they could cover more area, reach more people and accelerate the process of social change.

Sanjukta Sinha is a powerful case in point. Her rich professional life and her rising fame in the world of international business shaped her relationship with the Indian government. She cooperated with them by taking posts at public banks when asked. However, in her official capacity Sanjukta was not afraid to challenge the Indian government to expand their definition about what comprised good, ethical banking policies. Most of all, Sanjukta worked to hold her government responsible, on a state and federal level, for upholding the commitments they made and for enforcing their laws, because of their effects on real people.

This is most clearly seen in Sanjukta's stories about traveling the countryside as a representative of the agriculture rural development bank. On one memorable trip, she showed local governments how to move around funds so they could build bathrooms for schoolchildren in the countryside. Lack of private bathrooms was dangerous for all children as well as not in compliance with government policies. In this way, Sanjukta is similar to others I interviewed who confronted community police officers about their failure to comply with policies about domestic violence and other women's issues. She resisted the government's view that health care centers and toilets were not a part of rural infrastructure. However, she also knew that pushing the government is best accomplished with strong allies.

Sanjukta decided to connect with other organizations in the banking industry. While working as a government employee, she brought members of the banking industry together to facilitate change. She implored them: "Look you have to help us. We are a development finance institution. We also have a person in every district and at every state we have a big office. You can help us and we can help you. After all, we can provide you with a lot of very useful data." With her skill at negotiation,

11 See John D. McCarthy and Mayer N. Zald [26], who are the originators of the entrepreneurial version of resource theory. See Charles Tilly [27] who is a leading advocate of the political version of resource mobilization. 
Sanjukta created cooperative networks between the state bank and the commercial banks, and also among the commercial banks. By meeting to discuss data and strategy, bank chairs could spot areas of trouble and change their policies. This proved a much more efficient process for enacting social change than each bank working individually.

Wei Wang felt a certain modicum of protection through a global network that includes LGBT groups in Mainland China but also Taiwan, Hong Kong and even Chinese-American groups. She spread support for the LGBT cause by coordinating with existing local groups and helping people who wanted to create their own organizations. She provided new groups with training and set up support networks among LGBT organizations in China and abroad. By connecting local groups, Wei helped transform the LGBT movement into a national undertaking instead of isolated local actions. Her efforts created allies that could serve as liaisons to their specific communities, dealing with opinions and cultures specific to their area. She called her network of progressive organizations the "La-La Alliance", after the Chinese word for lesbian. The Chinese government is not comfortable with Wei's network. They were afraid of the potential impact of a national network such as this.

"So it's about different local groups who get together to form alliances so we can work on some joint action or coalition like we work towards like rights. And also this Chinese La-La Alliance is a cross regional network which definitely the government doesn't like. It doesn't like NGOs getting together and forming a network because then you will be stronger and have people in different areas to act on one thing, for example. So some of our work is risky, we have to prepare for that."

The government's discomfort confirmed that a "cross regional network" is often more effective than individual organizations working alone. Through the Internet, considered a "critical lever of globalization" by Ferree and Tripp [8], the movement has been able to reach more people and work within communities to garner support [1]. ${ }^{12}$ Having many groups working together also provides a level of security for Wei and other LGBT leaders. Even if the government shuts one of their groups down or one of them is arrested, the movement will continue. It is difficult to stop a movement that is present in every community across the nation. This multi-sited approach is a counterpoint to thwart government repression.

Just as Wei Wang benefited from coordinating with cross-regional and international networks, Leena Patel gained an ally in the American Association for Retired Persons, one of the U.S.'s largest lobbying groups. Leena had the idea to create an elder advocacy group, but because India had so little structure in place to help seniors and with the decline of the joint family, she looked abroad for specifics that she could use in her model. Leena's organization, Humanity, operates separately from AARP. Although the AARP wanted Humanity to become the "AARP of India," Leena did not transfer their exact model. She learned about the structure of AARP and gained knowledge through them, but she took those ideas and skills and applied them to her home country.

\section{The Interplay of Personal Transformation and Local Activism}

Social justice was each woman's early rallying cry, despite fundamental differences in state structure and state power in China and India. China's centralized, authoritarian state was targeted because of promises made by the Party in 1949 and onwards to create an egalitarian society [14]. In effect, Chinese women drew attention to the contradiction between what the Party promised and what it delivered. In India, by contrast, the ideology of democracy and rights for citizens led change

12 Mogahadam ([1], pp. 8-11) provides important examples of how the Internet and other forms of social media have mobilized other public protests in the U.S., Philippines, South Korea, and the Arab Spring of 2011. These organizations are not publically protesting in quite the same way. These large gathering at a local place for an event, such as a speaker or a dance, is a message to the government that is most likely watching. They are also targeting isolated individual women in rural areas using text messages to send information to individual rural women, such as a message against domestic violence and a number to call. 
agents to appeal to the government to use its resources to ameliorate the inequalities associated with economic change [15].

While there are many constraints on activism, a variety of resistance strategies have developed at the local level. Local struggles may not challenge structures and processes that exist beyond their local communities or region but they do become sites where important social justice work is taking place and where change-agents work to create a collective vision of a more just world ([28], p. 269).

As these women moved through moments of personal transformation, they built (and are building) more inclusive organizations capable of challenging local inequalities in important ways: (1) collaborating with their governments; (2) filling gaps governments cannot or will not address; and (3) where necessary working around their governments.

Sanjutka lobbied for policies that were sensitive to the cultural needs of rural citizens as well as financially sound. She negotiated with state governments, who control rural finances and policies, and collaborated with them in order to figure out ways to shift the states' budgets so that they could fund projects that the governments professed to support, in theory rather than reality, such as empowering rural women through microfinance and exchange of ideas, and bringing toilets to girls' schools. By filling gaps that exist in government services, the work of some women like Leena, is embraced by the government, as long as it fits with the social and political values that the government represents, such as aging populations left without family to care for them and in need of senior services or sexual violence centers (not featured in these selected narratives). Yet, this kind of pressure India's women place on their government does not often succeed in China.

Lijuan believes that the government should enforce their regulations and make this a priority over products produced, profits made and foreign investment. However, it seems to her that it is unlikely that she will ever get the government to rethink their agenda. She is part of a transnational legal aid organization but she says that the laws and policies in other countries do not help with the local organizing of farmers she is doing. Every time she disappoints China's rural farmers, who have grown to trust her, paradoxically she knows that the social media will be reporting the government win. These are not just men but also women whose rights to land ownership is a gendered and critical challenge in China [29]. The visibility of these cases on social media has led credibility to her cause.

Wei offers the strongest example of the practice of government avoidance through taking some activities underground. As Wei points out, it is legal to live this lifestyle, but LGBT people still do not have protections under the law and are actively suppressed; their activities occur in physical space. They censor themselves on certain subjects on their website (like the LGBT children's summer camp). However, through social media she has figured out how to subvert government censorship through a complicated communication based on text messages. Short text messages appear to be advertisements when they are in fact about women's rights. She also is part of a cross-regional network that mobilizes women against harassment. Social media and the Internet are crucial mechanisms utilized by these social change agents $[1,8]$. In effect, these case studies deepen our understanding of struggles that are unresolved and in flux.

\section{Conclusions}

The goal of this paper has been to deepen our understanding of how individual experiences and structural shifts lead some women to promote or redirect change. The use of stories has been helpful in two ways. First, they remind us that change is a human phenomenon. Second, they provide insights that cannot be deduced from survey responses or from observations of behavior at a distance. They reveal how individuals can be moved from observation to action to enlistment of others and ultimately to achieving a multiplier effect through the creation of networked resources.

In this sense, it is valuable to recall, as Giddens suggests, that in the post-traditional order, self-identity is reflexive. It is not a quality of a moment, but an account of a person's life. Giddens writes ([30], p. 54) that: 
"A person's identity is not to be found in behaviour, nor-important though this is—in the reactions of others, but in the capacity to keep a particular narrative going. The individual's biography, if she is to maintain regular interaction with others in the day-to-day world, cannot be wholly fictive. It must continually integrate events which occur in the external world, and sort them into the ongoing 'story' about the self." [Italics in Original]

In tracing the trajectory of these change agents from recognizing the tension of a double-bind to finding resolution in action, we are able to see the individual narrative take shape. To the observation of an injustice, a contradiction or a conflict between equally right answers, these women added deep empathy and an ability to imagine a different, more satisfying and perhaps a more just outcome. However, as they enlist others in their quest and discover power in numbers, they not only shape their own narrative but also they play a profound role in shaping others'. Future research on change-both the theory and the practice - can benefit from looking for similar moments in the lives of men and women in a much wider variety of settings.

Another question motivating the research had to do with feminism and change. To wit: what do these women and their stories tell us about the role of feminist ideology in the mobilization process? It is fair to conclude that these women are currently involved in mobilizing others in ways that are consistent with feminist activism. However, feminism goals were not always articulated as primary concerns. Indeed, none of the women interviewed in this study defined themselves initially as feminist activists. Even Wei Wang, whose organization is part of the present Chinese women's movement and a broader transnational network, took a hiatus in another country. She never imaged that her personal move to find a LGBT community in a non-hostile environment would result in her becoming an activist. The years spent abroad allowed her to figure out strategies that she could implement for mobilizing at home.

These women shared in common a preference for characterizing their work as aimed at social justice. In China especially, the focus on social justice has roots in both socialist ideology and dialogues stimulated by the 4th World Conference on Women held in Beijing. The younger women followed their lead in claiming that their feminist interventions were about social justice. In India, as noted earlier, the women's movement today is decentralized with smaller groups engaged in a multiple of activities. Yet, these women stories indicate that they are certainly mobilizing in ways to fight inequality. For example, Sanjutka did not ignore the rural women's and children's needs. Instead, she used her knowledge to aid in changing a system to benefit women and girls.

The focus on social justice underscores an important point made by Ferree and Tripp ([8], p. 9): "Feminists do many different things in real political contexts in order to accomplish their goals, and working in and through women's movements can be very important strategically. But especially when trying to see just how feminism as a goal is being advanced in and through a variety of transnational strategies, it becomes self-defeating to presuppose that only women's movements can be the carriers of feminism." In these examples feminist mobilizations remain essentially embedded in other priorities. However, this should not limit our overall concern that feminist activities and interventions are occurring.

A more effective approach to understanding feminist ideology in the mobilization process may be to expand the conversation to become more inclusive of actions that may remain embedded in other concerns (social justice, peace, anti-racism, etc.). While this begs the question of what becomes of feminist movements if the mobilizing actions occur as part of other priorities, the more important point is that feminism as a goal is still advanced.

Acknowledgments: I thank Alice Tzou who was my research assistant in China. She is now working on her $\mathrm{PhD}$ at CUNY in Sociology. I am grateful to Mamta Kapur who scheduled the India interviews. Wellesley research assistants Charlene Hou collected background data on potential interviewees while Claire Fogarty and Hadley Chase helped code the transcriptions. I also thank Robert J. Thomas, Anita I. Garey, Susan Reverby and Nancy Naples who listened, read, edited and helped me find threads that connected these women's lives. Wellesley College provided a faculty research award. A version of this paper was presented at the Eastern Sociological Society in 2012. In 2013, this project also became part of a methods symposium I gave at the University of Barcelona, Hosted by Research Group COPOLIS: Welfare, Community and Social Control, in Barcelona, Spain. 
Conflicts of Interest: The author declares no conflict of interest.

\section{References}

1. Valentine M. Moghadam. Globalization \& Social Movements, 2nd ed. Lanham: Rowman and Littlefield Publishers, Inc., 2013.

2. Joseph E. Stiglitz. Globalization and Its Discontents. London: W.W. Norton \& Company, 2002.

3. Robert J. Thomas. Crucibles of Leadership: How to Learn from Experience to Become a Great Leader. Boston: Harvard Business School Press, 2008.

4. Warren Bennis, and Robert J. Thomas. Greeks and Geezers: How Era, Values, and Defining Moments Shape Leadership. Boston: Harvard Business School Press, 2002.

5. Jyoti Puri. Woman, Body, Desire in Post-Colonial India: Narratives of Gender and Sexuality. London: Routledge, 1999.

6. Smitha Radhakrishnan. Appropriately Indian: Gender and Culture in a New Transnational Class. Durham: Duke University Press, 2011.

7. Arun Maira. Discordant Democrats. San Fransciso: Jossey-Bass, 2007.

8. Myra Marx Ferree, and Aili Mari Tripp. Global Feminism: Transnational Women's Activism, Organizing, and Human Rights. New York: New York University, 2006.

9. Rosanna Hertz, and Margaret K. Nelson. In-Depth-Interviewing of Parents and Children: Lessons from Donor-Conceived Families about How to Conduct Research on Sensitive Topics. Sage Research Methods Case Studies. London: Sage Publications, Ltd., 2016, in press.

10. Mark S. Granovetter. “The Strength of Weak Ties." The American Journal of Sociology 78 (1973): 1360-80. [CrossRef]

11. Kerry Brown. "China Challenges Civil Society." The Diplomat, 2011. Available online: http://thediplomat. com/2011/02/civil-society/ (accessed on 20 February 2011).

12. Edward Wong. "Clampdown in China Restricts 7,000 Foreign Organizations." New York Times, 28 April 2016. Available online: http://www.cnbc.com/2016/04/28/clampdown-in-china-restricts-7000-foreignorganizations.html (accessed on 5 January 2016).

13. Margaret Snyder. "Unlikely Godmother: The UN and the Global Women's Movement." In Global Feminism: Transnational Women's Activism, Organizing, and Human Rights. Edited by Myra Marx Ferree and Aili Mari Tripp. New York: New York University, 2006, pp. 24-50.

14. Ellen R. Judd. Women's Movement between State and Market. Palo Alto: Stanford University Press, 2002.

15. Rayka Ray. Fields of Protest: Women's Movement in India. Minneapolis: University of Minnesota, 1999.

16. C. Wright Mills. The Sociological Imagination. New York: Oxford University Press, 1959.

17. Brad Forenza, and Andrew J. Germak. "What Ignites and Sustains Activism: Exploring Participatory Competence." Journal of Progress Human Services 26 (2015): 229-45. [CrossRef]

18. Aldous Huxley. The Perennial Philosophy. New York: Harper Collins, 1990.

19. Albert O. Hirschman. Exit, Voice and Loyalty: Responses to Decline in Firms, Organizations, and States. Cambridge: Harvard University Press, 1970.

20. Human Rights Watch. "China: Enforced Disappearances a Growing Threat: Move to 'Legalize' Threatened Lawyers, Activists and Civil Society." 2011. Available online: https://www.hrw.org/news/2011/11/09/ china-enforced-disappearances-growing-threat (accessed on 11 September 2011).

21. Didi K Tatlow. "China Is Said to Force Closing Women's Legal Aid Center." New York Times, 29 January 2016. Available online: http://www.nytimes.com/2016/01/30/world/asia/beijing-women-legal-aid-guojianmei.html?mwrsm=Facebook\&_r=0 (accessed on 30 January 2016).

22. Shilpa Phadke, Sameera Khan, and Shilpa Ranade. Why Loiter?: Women and Risk on Mumbai Streets. New Delhi: Penguin Books, 2011.

23. Shilpa Phadke. "You Can Be Lonely in a Crowd: The Production of Safety in Mumbai." Indian Journal of Gender Studies 12 (2005): 41-62. [CrossRef]

24. Shilpa Phadke. "Dangerous Liaisons: Women and Men Risk and Reputation in Mumbai." Economic and Political Weekly: Review of Women's Studies 42 (2007): 1510-18.

25. Shilpa Ranade. "The Way She Moves: Everyday Production of Gender-Spaces." Economic and Political Weekly: Review of Women's Studies 42 (2007): 1519-26. 
26. John D. McCarthy, and Mayer N. Zald. "Resource Mobilization and Social Movements: A Partial Theory." American Journal of Sociology 82 (1977): 1212-41. [CrossRef]

27. Charles Tilly. From Mobilization to Revolution. Reading: Addison-Wesley, 1978.

28. Nancy A. Naples. "The Challenges and Possibilities of Transnational Feminist Praxis." In Women's Activism and Globalization: Linking Local Struggles and Transnational Politics. Edited by Nancy A. Naples and Manisha Desai. New York: Routledge, 2002, pp. 267-81.

29. Denise Hare, Li Yang, and Daniel Englander. "Land management in rural China and its gender implications." Feminist Economics 13 (2007): 35-61. [CrossRef]

30. Anthony Giddens. Modernity and Self-Identity: Self and Society in the Late Modern Age. Cambridge: Polity Press, 1991.

(C) 2016 by the author; licensee MDPI, Basel, Switzerland. This article is an open access article distributed under the terms and conditions of the Creative Commons Attribution (CC-BY) license (http://creativecommons.org/licenses/by/4.0/). 